DOI: 10.54631/VS.2021.S-92-102

\title{
AN IMAGINED WORSHIP: LOCALITIES AND CREATION OF REPRESENTATIONS IN CONTEMPORARY ĐẠO MÃ̃U
} Camille Senepin

\begin{abstract}
The worship of the Four Palace [Tú Phủ], recently named Đạo Mẫu [Mothers Godesses's Religion] can be found in Vietnam and is mainly present in the Northern part of the country. After years of prohibition and stigmatization, this Four Palaces are inscribed as Intangible Cultural Heritage of the Unesco in December 2016. The worship and its possession ritual [lên đồng] were mostly analysed in Hanoi by Western and Vietnamese researchers. In this article, the author proposeses an analysis of the dynamics of the Four Palaces outside Hanoi, linked to the semantic transformation taking place within the worship. The importance of the locality and how specific places can create singular discourses about the deities, the mediums and the devotees are emphasized in this communication. The author demonstrates that the Đạo Mẫu community is imagined. Nevertheless, the author analyses how the locality can modify the representations and the perceptions of the spirits embodied by the medium, depending on the localisation of the speakers. This paper also highlighted the consequences of the heritagization on the vocabulary and the contemporary practices, and how it can change the ones that are considered unorthodox. In this analysis the author also mentions the significance of those discourses inside the social medias, mostly on Facebook, which is one of the contemporary challenges of the worship.
\end{abstract}

Keywords: anthropology, religion, heritage, possession worship, vocabulary transformation, moral geography.

For citation: Senepin Camille (2021). An Imagined Worship: Localities and Creation of Representations in Contemporary Đạo Mẫu. Russian Journal of Vietnamese Studies, Special issue: 92-102.

\section{Introduction}

“The tenth Prince [Ông Hoàng Muò̀i] is from Nghệ An, he is from our home. Yes, but it's in Nam Định that he carries out more, he is important there!"

It was during a hot afternoon in May 2020 in Northern Vietnam, Ông Thắng and Chị Bích ${ }^{1}$, both followers of the "Four Palaces" [Tít phü], had this debate regarding the roots of the tenth Mandarin [Ông Hoàng Mườ], in the context of my inquiries on the spirit possession ritual [lên đồng]. I had arrived several days ago in Phủ Dầy, a northern Vietnamese place of worship constituted of a dozens of temples. Located in the village Kim Thái, Nam Định province, this place houses Liễu $H a n h^{2}$ 's mausoleum. This spirit is important within the northern practice of the worship of the Four Palaces. She would have supposedly lived in Nam Định province, place of her physical death. Thus, a majority of northern followers and spirit-mediums consider Nam Địh province as the "heart of the worship of the Four Palaces". This worship is also called the Mothers Goddesses worship [Thờ Mẫu], or, more recently, the Mothers Goddesses religion [Đạo Mẫu]. Besides a set of offering practices and propitiatory rituals, mediums of the Four Palaces organize possession rituals several times a year.

\footnotetext{
${ }^{1}$ Names have been anonymized.

${ }^{2}$ See Dror [2007] for more information regarding the earthly life of Liễu Hạnh.
} 
These religious specialists are followed by more or less important number of devotees, depending on the medium's reputation. This worship was stigmatized and forbidden for years during the repression against "superstitions" [mê tín dị doan]. Nowadays, the worship of the Four Palaces is pervasive in Vietnam, especially since its inscription as Intangible Cultural Heritage in December 2016. The worship of the Four Palaces has been studied and described by many authors since the 1950s (see in particular [Chauvet 2012], [Durand 1959], [Endres 2011], [Ngô Đức Thịnh 1996], [Nguyen Thi Hien 2015], [Simon et Simon-Barouh 1973], [Tran Van Toan 1966]). Nevertheless, many questions remain, even more since the heritagization of the worship in 2016. Most of the researchers have worked in the North of Vietnam, mainly in Hanoi, or have described the Northern form of the Four Palaces. If researchers like Kirsten Endres [2011] and Claire Chauvet [2012] studied, more or less deeply, the question of pilgrimages, they did not really explore the local peculiarities and practices of the Four Palaces that can be present in different places in Vietnam. It is important to focus on locality and leave the capital city in order to have a better understanding of the Four Palaces and its issues in the different part of Vietnam.

In this article, I will seek to understand the contemporary transformations that affect the Four Palaces by analysing the modifications of language, as new terminologies have been deployed since the beginning of the 21 st century and the recent worship's acceptance in Vietnam. I will emphasize the importance of the locality in the appearance of this terminology, and this analyse will be conducted with the concept of "imagined community" proposed by Benedict Anderson [2006]. In the first place, I will present the differences between the Northern rituals and those present in the Center of Vietnam, and how it can affect the ritual vocabulary. I will focus on locality as a main factor of variation, and how it can create "moral geography". By moral geography, I am inspired by David Smith's proposal [2000] which wishes to demonstrate that "geographical context is significant to moral practice" (preface VIII). In this article, by moral geography I mean the way humans create a moral imaginary, full of positive or negative conceptions, which they apply to other human groups, according to their physical locations. Groups from a particular place are expected to behave and think in a particular way, based on their location. By analysing moral geographies in etic ways, it is possible to understand how people locate other groups, physically and morally, and by extension themselves.

This paper will analyse how the semantic changes that appeared in recent years in Vietnam reveal modifications in the way the Four Palaces is perceived today in the country. Finally, I will examine how these developments have created new local representations, leading to the heritagization of the Four Palaces in 2016. This study stems from four fieldworks I conducted in Vietnam between 2017 and 2020. While materials used in this paper are from several participant observations of lên đồng, interviews with mediums, most of the data come from informal discussions with devotees and mediums. As the COVID-19 pandemic broke out I was not able to conduct fieldwork in Huế in 2020 and 2021 as planned, so I rely on the works of several researchers [Bertrand 1996; Dong Vinh 1999; Tran Van Toan 1966,1967] who conducted fieldwork in Hué ${ }^{3}$ to complete the analysis in this article.

\section{The worship of the Four Palaces: a variety of practices}

As I mentioned in the introduction, the worship of the Four Palaces has been studied by several authors, so as its possession ritual. The vocation of this article is not to produce an umpteenth description of the Four Palaces nor the conduct of the ritual, I will concentrate here on the differences between the Northern and Central rituals in Huế and show how it can affect the worship's conception.

${ }^{3}$ I am planning a fieldwork in Hué for the end of 2021. 
It is quite common to hear the medium say that thirty-six spirits make up the worship. These spirits live in Four Palaces [Tú phủ]:

- the Heaven Palace [Thiên phü]

- the Mountains and Forests Palace [Nhac phü]

- the Water Palace [Thoải phủ or Thủy Phủ]

- the Earth Palace [Địa phủ]

The Mothers [Mẫu or Thánh Mẫu] rules the Palaces. Next come the Mandarins [Quan Lónn], then the Ladies [Chầu], the Princes [Ông Hoàng], the Damsels [Cô], and finally the Little Princes [Cậu]. In fact this number is variable, and the spirits mentioned are not always the same. Each medium and devotees has their own vision of the worship, and how it should be practiced. Unlike to what the recent heritagization of the Four Palaces might suggest, the worship practices are not consistent. Differences are defined by the local context although this idea is absent of the UNESCO's consideration. In the North of Vietnam, the mediums embody the spirits following the hierarchical order during the possession ritual [lên đồng], the Mothers making only a brief descent and are not personified. Tran Van Toan [1966: 245] notices several differences in Huế: the Mothers are sometimes embodied and danced like the other spirits. Furthermore, the possession ritual begins with the descent of the female spirits [Ibid.], and not with the Mandarins. Most of the time is taken by the manifestation of the spirits of the Mount and Forest Palace [Ibid.: 247]. Finally, whereas in the North the medium officiates alone, a co-celebration is noticeable in Huế: several religious specialists embody the spirits from the same rank all at once ${ }^{4}$ [Ibid.: 245], activity that Didier Bertrand also noticed [1996: 278, 279]. This co-celebration is still practiced by mediums from the Center of Vietnam nowadays, as I was able to watch through videos shot in 2017 at Nguyệt Du Cung Temple, where mediums from Huế were invited to perform.

Tran Van Toan also notes that only rich people in Central Vietnam can embody spirits from higher ranks, and that the spirits of the Mountains and Forests are more mostly embodied by workers [1966: 89]. This difference cannot be found today in the North of the country and has not been noted by other researchers who have worked on northern Vietnam. However, the question of wealth is quite interesting: the Four Palaces rituals need a large amount of money to be conducted correctly. A lot of devotees consider the worship as a "religion for rich people". The major expenditure required by the worship was strongly criticized by the Vietnamese government between the 1950s and 1990s. However, since the Four Palaces' inscription as Intangible Heritage of the UNESCO, items requiring significant expenditure, such as ceremonial robes or votive objects, are now highlighted and can be used to represent Vietnamese culture, as it is possible to see in Women Museum in Hanoi [Bảo tàng Phu nũ Việt Nam] where we can find an exhibition about Đạo Mẫu (Fig. 1). Once, for the government, those objects were seen as useless and a wasteful use of money, while they are now one of the main components of the heritagization of the worship. The process of transformation in the Vietnamese society that led to the acceptance of the Four Palaces in the Vietnamese public space are complex. It follows a will of the Party since the Đổi mói in 1986 [see Malarney 2002] but also the ambition of some Vietnamese researchers to rehabilitate the worship, particularly thanks to the works of Ngô Đức Thịnh, who leaded fieldwork in Nam Định [1996, 1999, 2003].

\footnotetext{
${ }^{4}$ Only the Mother of the Mount and Forest Palace can be embodied with spirits of lower rank [Ibid.: 245].
} 


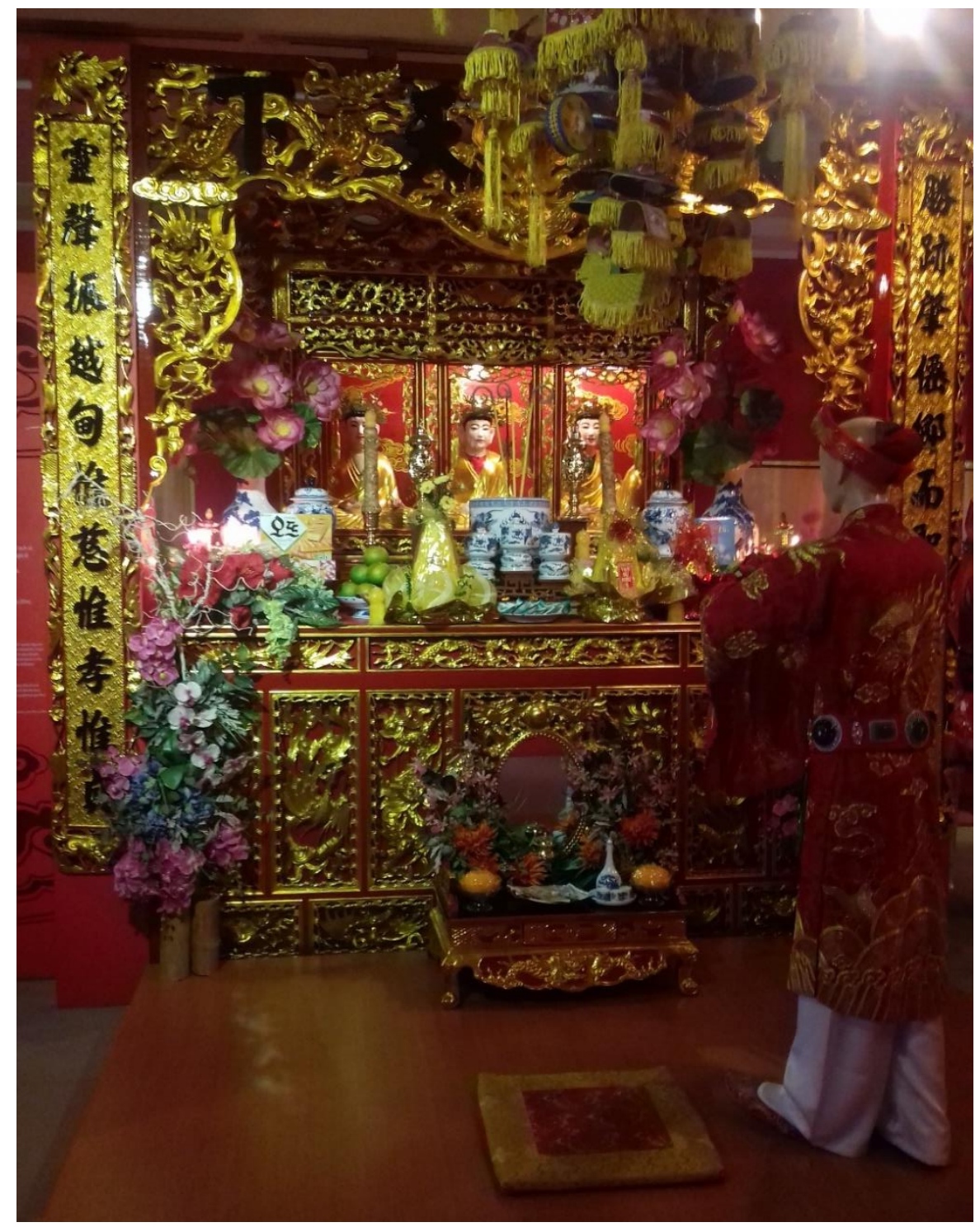

Fig. 1. Exhibition in the Women Museum, 2018. Photo by the author

Those transformations lead to a modification of the position of the worship of the Four Palaces, which is very popular nowadays. While it was banned for almost forty years, it is now possible to see it on television, on the internet or on a theatre stage. The worship's position on internet deserves particular attention and should be more investigate. Social medias like Facebook, YouTube and more recently TikTok are a fresh space for information's transmission, self-representation, or streaming of rituals directly by the devotees, while the ones present in the official broadcast channels are highly smoothed, which do not correspond with the daily ritual practice of the devotees. Voices are being raised against these activities, which are seen as a commodification of the Four Palaces, away from the worship's "good practice". Despite a desire to unify the worship, whether it comes from the Party or the mediums, through medias or through the inscription as Intangible Cultural Heritage, several visions of worship can still be found, especially as different perspectives exist among practitioners. As Shawn Malarney points out, "what we have is a cacophony of voices, each defining its own vision of how things should be" [2002: 3]. The first notable differences concerning the worship of the Four Palaces is the vocabulary transformations, consequences of contemporary mutations of the worship. 


\section{Semantic transformation as a tool to understand contemporary and local changes}

It is striking to observe that the vocabulary linked to the Four Palaces is multiple. First of all, in France, the translation of "worship of the Four Palaces" is adopted since Maurice Durand's monograph [1959] and the work of Simon and Simon-Barouh [1973]. However, in Vietnam there are at least four terms to talk about this worship. The first one is Tú phü, meaning Four Palaces, which is the translation used in English and French. The second is Thơ Mẫu, which could be translated as Worship of the Mothers. The third one is Tam phu, which means Three Palaces. The last and most recent one is Đạo Mẫu, which can be translated as Religion of the Mothers. Then, why speak of three [Tam phü] or four Palaces [Tú phü]? According to several interlocutors, the worship initially included only three Palaces. Several followers said that a fourth Palace was added to the worship belatedly. While Kirsten Endres [2011] and Thaveeporn Vasavakul [2003] note that the Palace of Mountains and Forests was the one that would have been added, several worship's followers pointed out to me that it was rather the Palace of the Earth. The debate concerning the number of Palaces is still ongoing today, researchers and religious specialists do not agree among themselves on the exact origin of the Palaces. It is striking to see that Tam phu is the chosen name for the worship's UNESCO inscription ${ }^{5}$ (Fig.2). In addition to the fact that the UNESCO's investigation was mainly conducted in Nam Địn's province, therefore limiting the analysis of different practices, Tam phu is rarely used in the discourses the followers. The use of this term reveals a dysfunction between the international institution's language, and by extension the State, and rituals practices.

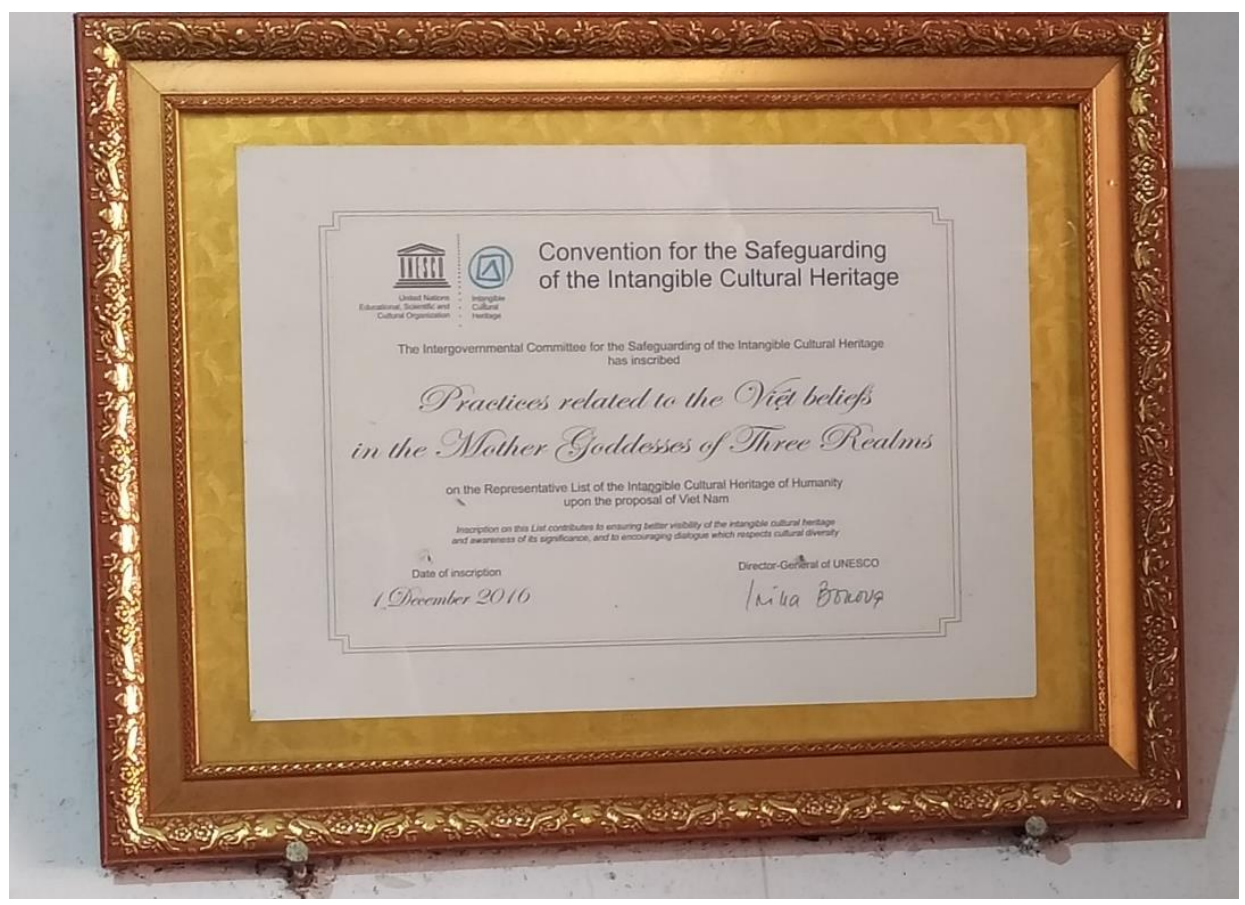

Fig. 2. UNESCO convention displayed on a wall in Nguyệt Du Cung temple, 2020. Photo by the author

According to Dorais and Nguyen Huy [1998], the addition of a fourth Palace would be the consequence of a redefinition of Vietnamese cosmographic thought at the end of the Chinese occupation, and "perhaps the erasure of prehistoric Viet religion behind the religious philosophies introduced from China" [Ibid: 193]. The influence of Taoism and Chinese culture is not insignificant,

5 The full name is "Practices related to the Viet beliefs in the Mother Goddesses of Three Realms", or "Tín ngương thờ Mẫu Tam Phủ của Ngườ Việt”. 
as the construction of deities' hierarchical construction is not unlike that of Taoism. Nevertheless, I will not develop here these questions, already evoked in the works of Durand [1959], Nguyen Thi Hien [2015] and Simon and Simon-Barouh [1973], but rather I will focus later in this paper on the influence of the Cham, which has not been mentioned much in the context of the Four Palaces.

Dorais and Nguyen Huy also signal that this worship has Vietnamese particularities because of the women predominance in ritual practice [Ibid: 194]. I would qualify this statement by pointing out that beyond the female figures, whether divine or earthly, the spirits of the Four Palaces are all, more or less, heroes who have contributed to the victories of the Đại Viẹt and its administrative and social organization. However, focusing on the presence of divine or earthly feminine figures in the Four Palaces fails to consider the fact that numerous spirits are linked to significant historical characters of Đại Viẹt history. This might be a better indication of the worship's indigenous character. The Vietnamese Party seeks to emphasize this point, in order to make the worship a Vietnamese and orthodox religion, like the "state functionalism" that Malarney [2002] describes, where high-ranking Party members seek to use ritual for political and ideological purposes, like using the UNESCO's inscription to have a better monitoring on the worship.

It is striking to see that these terminological variations occur rapidly. Before Ngô Đức Thịnh's book [1996], that suggested the term Đạo Mẫu, the notion of "religion of the Mothers" was hardly used in common language. Nowadays, it became a term that we can easily find, and was adopted by most of the devotees. Since 2017 and my first fieldwork in Vietnam, I have witnessed the increasing use of this term, which is derived from a recent invention created by Vietnamese folklorists [Endres 2011]. By qualifying it as Đạo [religion], these intellectuals took part in the recent rewriting of the Four Palaces, taking it out the realm of "superstitions" and placing it in "modern" Vietnam, where it is accepted, even encouraged if it follows state directives. This transformation is the result of a vision change at the state level since 1986, but also due to the efforts of several Vietnamese researchers who have sought to legitimize this "folk religion" within nationalist and cultural terms [Norton 2009]. Although some Vietnamese people still consider this worship as superstitious and backward, it is worthy of noting that many followers and mediums have adopted the revolutionary discourse, while following some of the Party's directives (see notably [Endres 2011; Norton 2009]). Thus, in the discourses of mediums and followers, orthodox practices are considered as beneficial and appropriate, while others are rejected because they still are considered as superstitious [Ibid].

The utilization of the term " $Đ a ̣$ " is even more significant as Vietnam has not recognised Đạo Mẫu as an "official religion" by the State. This difference is noticeable in the official name given to the worship in UNESCO, where belief [tín nguõng] is used, rather than religion [Đạo], thereby limiting the religious character of worship. It is interesting to draw a parallel between the Four Palaces and Hòa Hảo Buddhism and Caodaism cult that have managed to achieve the status of "official religions" according to an official decision, not without sacrifices. Jérémy Jammes [2011] notes in the case of Caodaism that despite Vietnamese directives regarding religious freedom, only the orthodox branches of the cult receive the necessary authorisations to broadcast announcement during religious ceremonies, to carry out media activities, or proselytizing [Ibid: 283]. If several mediums seek to organise themselves into an association to organise the Four Palaces in order to become an "official religion", one can wonder what impact this can have on their practice. Further recognition does not imply absence of state interference, quite the contrary in fact. Philip Taylor [2004] stresses this point which may seem paradoxical. In the context of the Bà Chúa Xíu [Lady of the Realm] worship

${ }^{6}$ I thank Binh Tran, PhD Student in Auckland University for this reminder. 
in southern Vietnam, the contemporary renewed practice is due to an increased presence of the state and not as an absence of it, as the Party has shaped the worship's organisation there [Ibid: 24, 25]. Thus, as Oscar Salemink notes, "heritagisation constitutes an appropriation of the past and thus an attempt to control the future by certain elites that alienate other groups in the process" [2016: 314]. In the case of the Four Palaces, it is possible to imagine that its heritagization and its possible ratification as an "official religion" will not lead to greater freedom but rather a process of a standardization of practices, in favour of the one that have the preference of the state.

Besides the semantic changes concerning the worship, the names attributed to the mediums also gradually transformed. Maurice Durand uses the terms bà đồng and cô đồng in his book [1959] to refer to female mediums. Bà đồng and ông đồng are the most commonly used terms in anthropological literature to refer to female and male mediums. Yet, in practice, there are a multitude of terminologies to define a medium of the Four Palace. For example, $C u$ đồng refers to old mediums, Tân đồng to a young medium who has been performing for a maximum of three years, or Đồng thầy is used for the mediums masters, sharing their knowledge and training new mediums (see [Endres 2011] on training of mediums). Nowadays, it seems that the title Thanh đồng is the most widely used by the devotees. Thanh represents purity, while đồng refers to mediumship. This term is used to refer to mediums whether they are men or women. The widening acceptance of this denomination today is interesting because it seems to belong initially to Trần Hưng Đạo worship and was only used for men as Pham Quynh Phuong notes in her book [2009]. While Trần Hưng Đạo and the Four Palaces worship were distinct, with different religious specialists separated by gender, they seem to combine since the 1990's. By using thanh đồng to refer to the mediums of the Four Palaces, it no longer discriminates them according to gender ${ }^{7}$ while erasing the previous distinction between Trần Hưng Đạo and the Four Palaces worship.

By analysing the semantic changes concerning the worship of the Four Palaces, we can have a greater view of contemporary dynamics that have gone and still go through the worship. The Vietnamese State's change in policy has a significant influence over the new status of the Four Palaces, although the followers of the worship have also played an important role in it.

\section{Locality and relative imagination of the Four Palaces}

The followers' spatial location in the region of Vietnam takes a part in the relationship and appropriation of the spirits, but also in the relationship between the followers themselves. The principal temples where the spirits of the Four Palaces are venerated are related to their earthly life and achievement. Here are a few examples: the main temple of the Tenth Prince [Ông Hoàng Muời] is located in Nghẹ An province, his supposed origin. The Temple of the Seventh Prince [Ông Hoàng Bảy] is located in Lào Cai, near the Chinese border. The main temple of Thiên Y A Na is in Huế. Finally, the high place of worship of Liễu Hạnh is Phủ Dầy. Those places are related to the spirits' activities during their earthly life: it can be the place of their births or deaths, as the Tenth Prince or Liê̂u Hạnh temples, where they worked or lived as the Seventh Prince or Thiên Y A Na principal temples. The location of these temples plays an important role in the links between the devotees and the spirits. Nam Định province followers, and those in northern Vietnam, consider Liễu Hạh as the most important spirit of the Four Palaces, in contrast to followers living in the centre of the country, for whom Thiên Y A Na plays this role. These different take on of the worship are important in the follower's movements and perceptions. Several northern informants I talked to did not even deem

${ }^{7}$ Concerning gender in the Four Palaces, see in particular [Tran and Filax 2018]. 
that a form of Tú phu could exist in the centre of the country, or at least not a "real" one. While I have seen pilgrims from central and southern Vietnam come to the north, I have never heard of pilgrimages from the North to Huế or Ho Chi Minh City. This point highlights the cultural hegemony that the North of the country operates in the case of the Four Palaces.

Beyond this hegemony, it is worth to note that followers of the Four Palaces belong to an imagined community ${ }^{8}$. Imagined because this community shares particular conceptions, images and representations, without confronting them on a daily basis with other followers, but also without meeting all the practitioners of the Four Palaces. A distinction must be made between this imagined, extended community, which brings together the followers who share a common imagination, and the much more restricted community that is organised around a medium. The followers go on pilgrimage with the religious specialist, following him on his travels to different temples where he organises possession rituals. They get to know each other, discuss together, and create a common vision of the worship. Those different groups may meet at festivals, such as the Phủ Dày festival [Lễ hôi Phủ Dày] in the North of the country (Fig. 3) or the Hòn Chén festival [Lễ hội Điện Hòn Chén] in Huế, or even in rituals organised in temples or on pilgrimage. The devotees confront their ideas and representations. During those discussions local importance given to certain spirits, different ritual practices or even differences concerning the spirits' hagiographies can be note and discussed.

During these encounters, it is also possible to see the representations apply directly to the groups according to their origins. During my fieldwork in Phủ Dầy, up to three mediums were present each day to organise possession rituals. Coming from Hanoi, Hải Dưong or Nghệ An province, I had to choose which ritual to attend. On one day, two ceremonies were held in parallel. One group of devotees was coming from Hải Duoong, while the second was arriving from Hanoi. When I asked Tung, one of the temple residents, which ceremony would be more interesting, he replied without hesitation to go to the Hanoi group. According to him, this group was more interesting because it came from the capital, even if the medium was not particularly well known nor talented. The ceremony had a few hitches, notably because of the large number of ghosts that visited some of the spectators. The fact that I was directed to this medium was clearly due to his origin. Being from the capital is a sign of success for several reasons. The first is that many famous mediums live in Hanoi. The second is the historical opposition between capital and province, and even more between rural and urban areas. A form of "moral geography" is indeed being set up: images and preconceptions are projected on what the mediums of a particular place should be and should behave. Thus, the mediums of Phủ Dày are supposed to be guarantors of a certain form of "tradition", while the Hanoian mediums are supposedly wealthier, offering very aesthetic rituals. Obviously, reality rarely fits these projected images. It is important to understand how these projected images are constructed, and what consequences they may have on the ritual practice of worship which should be the object of future research.

${ }^{8}$ I borrow this expression from Benedict Anderson [2006]. 


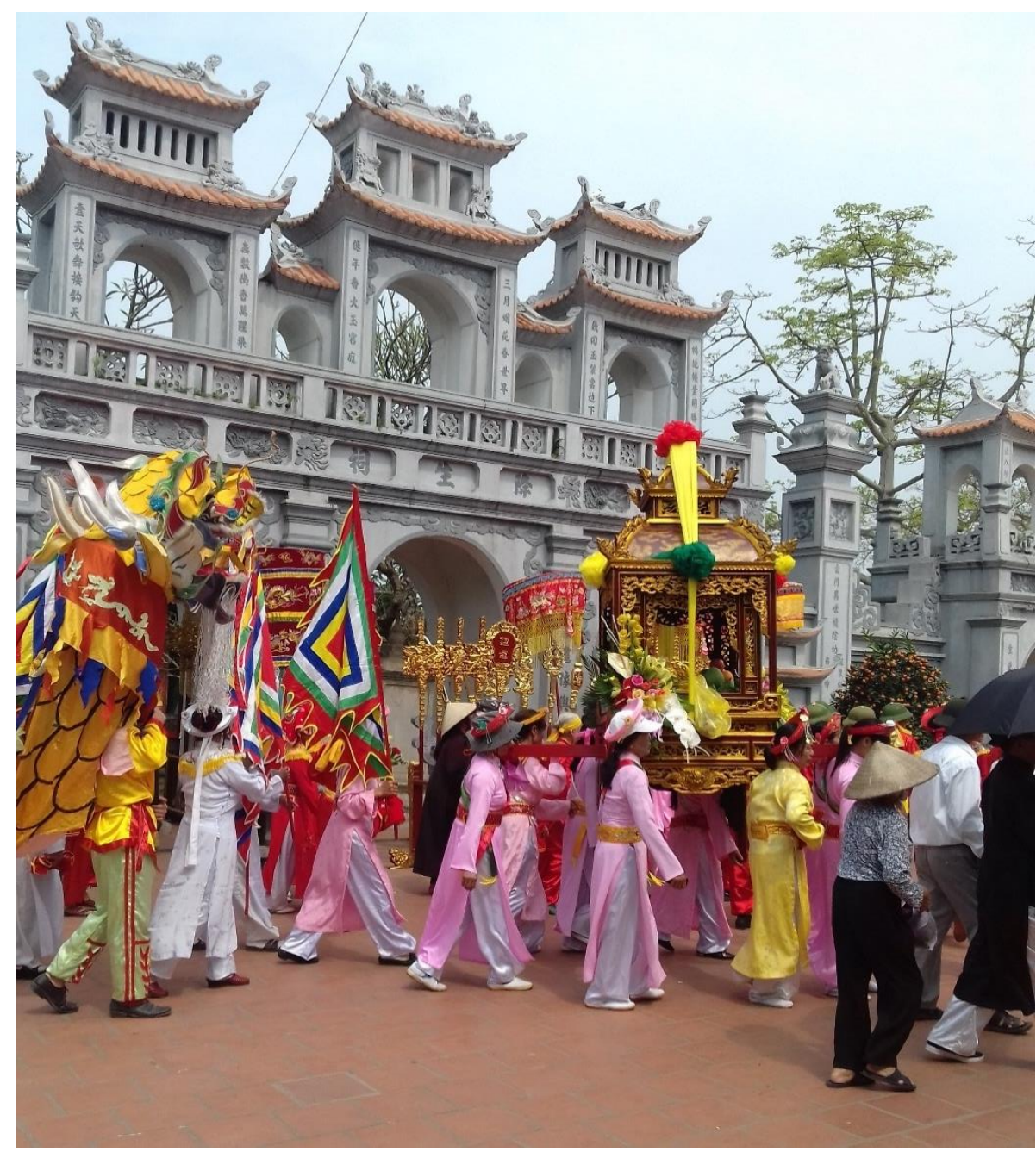

Fig. 3. Procession during Phủ Dầy festival, 2018. Photo by the author

Locality matters in the representation of worship itself. Dong Vinh points out that for devotees in central Vietnam, the country is ruled by three deities: Liếu Hạnh in the North, Thiên Y A Na in the centre, and Bà Đen in the south [1999: 77]. In addition, Tran Van Toan notes that the followers in the centre of the country seem to attach a great importance to the spirits of the Mountains and Forests, remnant with the past relations with the $\mathrm{Cham}^{9}$ [1966: 90). The Cham influence has been erased in favour of a culturally united and dominant Vietnam, and, as I suggest before, is too often forgotten in the analysis of the Four Palaces. However, traces of the influence of the ancient kingdom of Champa are still visible today in the Four Palaces, whether through the Vietnamisation of the goddess Po Nagar (see [Nguyen 1995]) or in the importance of the spirits of the Mountains and Forests (see [Tran Van Toan 1966 and 1967]). These relations commonalities, borrowings and syncretism that have taken place between Cham and $\mathrm{Kinh}^{10}$ since the conquest led by the Đại Việt are still too often underestimated and cannot be ignored. Without seeking to achieve a complete historical analysis of the history of the Four Palaces worship in central Vietnam, it is important to note the differences in practices, imaginations and symbols between the rituals conducted in the North of the country and those present in Hué.

\footnotetext{
${ }^{9}$ The Cham were the majority ethnic group of the Champa kingdom, which dominated for a long time central and southern Vietnam.

${ }^{10}$ Also called Viet, the Kinh are the dominant ethnic group in Vietnam.
} 


\section{Conclusion}

The contemporary transformations of the worship of the Four Palaces are the consequences of actions conducted by the Vietnamese government, along with several researchers, but it is also the result of the devotees' efforts to regain ownership over their ritual practices. In that sense, we can follow the Vietnam's ongoing national construction through the worship. As I have shown, the modification of the vocabulary of the Four Palaces allows us to grasp on a larger scale the contemporary transformations of the worship. The importance of the localities is not insignificant as demonstrated in this article, and indicates how representations and perceptions are perpetually changing, not unrelated to the country's long separation. Moral geography is a useful tool that researchers can use to understand the imaginary constructed between several groups, and can explain the community dynamics. Thus, we can extend Catherine Bell's theory about ritualization to the worship of the Four Places, which says that ritualization "does not see how it actively creates place, force, event and tradition, how it redefines or generates the circumstances to which it is responding" even if ritualization is supposed to be a response to place, force, event and tradition [Bell 2009: 109]. In the case of contemporary Đạo Mẫu, if the worship sees itself as a response to an ancestral tradition, in specific places with particular events, but it does not see how the worship creates a hegemonic tradition in northern Vietnam. The domination of the northern practices forgets, even ignores, the different forms of local practices such as the one in Huế and imposes semantic transformations. Consequently, it is necessary to move away from the north of Vietnam and its hegemonic circle of influence to capture aspects of contemporary worship that is too frequently omitted.

\section{References}

Anderson B. (2006). Imagined Communities: Reflections on the Origin and Spread of Nationalism. Verso.

Bell C. (2009). Ritual theory, ritual practice. Oxford: Oxford University Press.

Bertrand D. (1996). Renaissance du lên dõng à Huẽ (Việt Nam). Premiers éléments d'une recherche [Renaissance of lên dõng in Huẽ (Việt Nam). First Elements of a Research]. Bulletin de l'Ecole Française d'Extrême-Orient, 83: 271-285.

Chauvet C. (2012). Sous le voile rouge. Rituels de possession et réseaux cultuels à Hà Nội (Việt Nam) [Under the Red Veil. Possession Rituals and Worship Networks in Hà Nội (Việt Nam)]. Paris: Les Indes Savantes.

Dong Vinh (1999). Le culte des Saintes-Mères (Dao Mâu) dans le Vietnam Central [The cult of the Holy Mothers (Dao Mâu) in Central Vietnam]. Études vietnamiennes, 131: 77-86.

Dorais L.-J., Nguyen Huy (1998). Le Tho Mâu, un chamanisme vietnamien? [The Tho Mâu, a Vietnamese Shamanism?] Anthropologie et Sociétés, 22 (2): 183-209.

Durand M. (1959). Technique et panthéon des médiums vietnamiens (dong) [Vietnamese technique and pantheon of mediums (dong)]. Paris, EFEO.

Dror O. (2007). Cult, Culture, and Authority: Princess Lieu Hanh in Vietnamese History. Honolulu: University of Hawai'i Press.

Endres K.W. (2011). Performing the Divine: Mediums, Markets and Modernity in Urban Vietnam. Copenhagen: NIAS Press.

Jammes J. (2011). La répression comme fonction sociale complexe. L'État vietnamien face au mouvement Cao Dai de 1975 à nos jours, in: A. Brotons, Y. Brunneton, N. Kouame. État, religion et répression en Asie. Chine, Corée, Japon, Vietnam (XIIIe-XXIe siècles) [Repression as a Complex Social Function. The Vietnamese State Facing the Cao Dai Movement from 1975 to the Present Day, in: State, Religion and Repression in Asia. China, Korea, Japan, Vietnam (13th-21st Centuries)]. Paris: Karthala: 263-310. 
Malarney Sh.K. (2002). Culture, Ritual and Revolution in Vietnam. Honolulu: Université of Hawai'i press.

Ngô Đức Thịnh (1996). Đạo mẫu ở Việt Nam [The Mother Goddess Religion in Vietnam]. Hanoi: Nxb Văn Hóa - Thông Tin.

Ngô Đức Thịnh (1999). Le panthéon du culte des Saintes Mères (Đạo Mẫu) [The Pantheon of the Cult of the Holy Mothers (Đạo Mẫu)]. Études vietnamiennes, 131: 19-34.

Ngô Đức Thịnh (2003). Len dong: Spirits’ Journeys, in: Nguyen Van Huy, K. Laurel (eds.). Journeys of Body, Mind and Spirit. Berkeley: University of California Press: 253-272.

Nguyen Thi Hien (2015). The religion of the Four Palaces. Mediumship and Therapy in Viet Culture. Saarbrücken: Lambert Academic Publishing.

Nguyen The Anh (1995). The Vietnamization of the Cham Deity Pô Nagar. Asia Journal, 2(1):55-67.

Norton B. Songs for Spirits: Music and Mediums in Modern Vietnam. Urbana: University of Illinois Press.

Phạm Quỳnh Phương (2009). Hero and Deity: Tran Hung Dao and the Resurgence of Popular Religion in Vietnam. Chiang Mai: Mekong Press.

Salemink O. (2016). Described, Inscribed, Written Off: Heritagisation as (Dis)connection, in: Ph. Taylor (ed.). Connected and Disconnected in Vietnam. Remaking Social Relations in a Post-Socialist Nation. Canberra: ANU Press: 311-346.

Simon P.J, Simon-Barouh I. (1973). Hâù Bóng, Un culte viêtnamien de possession transplanté en France [Hầ Bóng, A Vietnamese Possession Cult Transplanted to France]. Paris: Mouton.

Smith D. (2000). Moral Geographies. Ethics in a World of Difference. Edinburgh: Edinburgh University Press.

Taylor Ph. (2004). Goddess on the Rise. Pilgrimage and Popular Religion in Vietnam. Honolulu: University of Hawai'i Press.

Tran Thi Thuy Binh, Filax G. (2018). Social effects of Dao Mau. Regional Journal of Southeast Asian Studies, 3 (1): 2-25.

Tran Van Toan (1966). La sainte religion de l'immortelle céleste dans la région de Huế (Centre Vietnam) [The holy religion of the celestial immortal in the Huế region (Central Vietnam)]. Revue du Sud-Est Asiatique, 1: 77-102; 2: 241-258.

Tran Van Toan (1967). La sainte religion de l'immortelle céleste dans la région de Huế (Centre Vietnam) [The holy religion of the celestial immortal in the Huế region (Central Vietnam)]. Revue du Sud-Est Asiatique, 1: 103-130.

Vasavakul Th. (2003). From Fence-Breaking to Networking: Interests, Popular Organizations and Policy Influences in Post-Socialism Vietnam », in: B.J.T. Kerkvliet, H.K. Russel., D. Koh. Getting Organized in Vietnam. Moving in and Around the Socialist State. Singapore: ISEAS: 25-61.

\section{Author:}

Camille Senepin, PhD Candidate, School of Advanced Studies in the Social Sciences (EHESS), Center for Southeast Asian Studies (CASE), Paris. E-mail: camille.snp@gmail.com 